\title{
Mechanical Behavior of Coal Specimen under Pore Gas Pressure
}

by Tatsuhiko GOTO ${ }^{1}$, Tateki SATO ${ }^{1}$, Jun-ichi KODAMA ${ }^{1}$ and Gouta DEGUCHI ${ }^{2}$

1. Muroran Institute of Technology, Mizumoyo-cho, Muroran 050

2. The Coal Mining Research Center, Chiyoda-ku, Tokyo 101

\begin{abstract}
To investigate the mechanical behavior of coal specimens with the pore gas pressure, the following laboratory experiments on coal collected from Ashibestu and Akabira Coal Mine were conducted; the triaxial compression tests and those with the pore gas pressure by useing the triaxial testing machine under the condition of the strain rate of $1.3 \times 10^{-4} / \mathrm{sec}$ and confining pressure and pore gas pressure extending up to $40 \mathrm{MPa}$, the gas permeability tests under the hydrostatic pressure by means of the transient pulse method.

The experiments showed that coal strength increased and brittle behavior became predominant with the increase of the effective confining pressure. The law of effective stress for the fracture criterion was valid for coal specimens whose pore were fully saturated with gas pressure.

As the experimental results, the coal specimens were more permeable under the low hydrostatic pressure than under the high hydrostatic pressure, and these phenomena and deformation were largely concerned with the collapse processes of cracks in a coal specimen under the hydrostatic pressure.
\end{abstract}

KEY WORDS : Pore Gas Pressure, Coal, Confining Pressure, Mechanical Behavior

\section{1. 緒}

地下に存在する石炭は周囲から地圧を受けるのみならず，しばし ばその亀裂内にガス圧を有する場合がある。このガス圧と地圧との 相互作用がガス突出等を誘起する要因の一つとも考えられている。 筆者らは石炭の力学的性質を把握するため, 従来より封圧下での試 験を実施してきており，その結果，石炭は岩石とは異なった挙動を 有することがわかった ${ }^{11}$ 。

一方, 間隙流体压を考慮した封圧試験に関しては, 流体として水 を使用し, 岩石を対象とした研究が進んでおり, そのデー夕の蓄積 屯多( 2)-4)。しかしながら, 間隙ガス圧を含む石炭の変形や破壊挙 動の計測 ${ }^{5)}$ については, 炭鉱でのガス抜きやガス突出の観点から重 要ではあるにあかかわらず, 多数の供試体確保の困難性等のためあ まり実施されていない実状にあり, 石炭に対しては, むしろガス透 過性に着目した研究が一般的である゙ ${ }^{6)}$ 。

本研究では芦別㧍よび赤平炭鉱で採取した 5 種の石炭供試体を対 象に, ひずみ速度 $1.3 \times 10^{-4} / \mathrm{sec}$, 封圧, 間隙ガス圧を $40 \mathrm{MPa}$ 以 下の範囲内で封圧試験, 窒素ガスを用いた間隙ガス圧試験を実施し た。また間隙ガス圧試験に先立ち，定性的ではあるが，封圧下にお けるガス透過性試験む若干試みた。その結果, 間隙ガス圧が石炭の

\footnotetext{
* 1994 年 1 月 17 日受付 2 月 21 日受理 資源・素材学会平成元年度春季大 会にて一部発表

1. 正会員 工博·室蘭工業大学助教授 工学部材料物性工学科

2. 正会員 工博 室蘭工業大学教授 工学部材料物性工学科

3. 正会員 室蘭工業大学助手 工学部材料物性工学科

4. 正会員 工博 石炭技術研究所

キーワード：間隙ガス圧, 石炭, 封圧, 力学的挙動
}

力学的挙動に及ぼす影響, ならびにガス透過性と封圧の関連性等に ついて興味ある知見が得られたので，報告する。

\section{2. 供試体}

芦別炭鉱および赤平炭鉱で採取した一辺が $30 \mathrm{~cm}$ 程度の石炭ブロッ クを室内に持ち帰り, カッ夕で切断後, 縦, 横約 $30 \mathrm{~mm}$, 高さ約 60 $\mathrm{mm}$ の直方体に表面研削盤で乾式整形したものを供試体とした。 なお各面の端面精度はいずれも $\pm 2 / 100 \mathrm{~mm}$ 以内で, 載荷軸方向が 成層面と垂直になるように仕上げた。

芦別炭鉱での供試体の採取場所はー790およびー885レベルで，い ずれも 8 番層炭である。ここではこれらを $\mathrm{AS}-(\mathrm{A}), \mathrm{AS}-(\mathrm{B})$ と 呼ぶことにする。一方, 赤平炭鉱の一 690 レベルでの採取場所の異 なる 2 種の 8 番層炭を $\mathrm{AK}-(\mathrm{A}), \mathrm{AK}-(\mathrm{B}),-550$ レベルの 8 番 層炭を $\mathrm{AK}-(\mathrm{C})$ とそれぞれ呼ぶことにする。

Table 1 はこれら供試体の真比重, 見掛け比重, 空隙率および一 軸圧縮強度を示したものである。測定值はいずれも 5 個の試料の平 均值であり, 表には標準偏差も同時に示してある。なお見掛け比重 測定は数十グラム程度の試料を対象に行った。一軸圧縮強度のばら つきが比較的大きいが, 真比重, 見掛け比重の測定值に関しては, ばらつきは小さい。 AS- (B), AK- (C) 供試体の空隙率は他に 比べ大きく, $\mathrm{AK}-(\mathrm{A})$ 供試体の空隙率は小さく, 一軸圧縮強度が 大きいことがわかる。

整形後の供試体は数週間デシケータ内に保存後, 上下面にエンド ピースを取り付け, 封圧流体の浸入を防ぐため周囲を生ゴム, シリ コンゴムで被覆し実験に供した。なお間隙ガス圧試験用エンドピー スの中央には, ガスの供給を可能にするため, $2 \mathrm{~mm}$ の細孔が設け 
Table 1 Physical properties of coal specimens.

\begin{tabular}{|c|c|c|c|c|c|}
\hline site & \multicolumn{2}{|c|}{ ASHIBE TSU } & \multicolumn{3}{c|}{ AKABIRA } \\
\hline symbol & AS-(A) & AS -(B) & AK-(A) & AK-(B) & AK-(C) \\
\hline depth (m) & -790 & -855 & -690 & -690 & -550 \\
\hline $\begin{array}{c}\text { seam } \\
\text { number }\end{array}$ & 8 & 8 & 8 & 8 & 8 \\
\hline $\begin{array}{c}\text { true specific } \\
\text { gravity }\end{array}$ & $\begin{array}{c}1.30 \\
(0.03)\end{array}$ & $\begin{array}{c}1.32 \\
(0.02)\end{array}$ & $\begin{array}{c}1.31 \\
(0.02)\end{array}$ & $\begin{array}{c}1.35 \\
(0.04)\end{array}$ & $\begin{array}{c}1.30 \\
(0.03)\end{array}$ \\
\hline $\begin{array}{l}\text { apparent spe- } \\
\text { cific gravity }\end{array}$ & $\begin{array}{c}1.27 \\
(0.01)\end{array}$ & $\begin{array}{c}1.24 \\
(0.01)\end{array}$ & $\begin{array}{c}1.29 \\
(0.02)\end{array}$ & $\begin{array}{c}1.31 \\
(0.03)\end{array}$ & $\begin{array}{c}1.23 \\
(0.05)\end{array}$ \\
\hline porosity(\%) & 2.31 & 6.81 & 1.10 & 2.96 & 5.38 \\
\hline $\begin{array}{l}\text { compressive } \\
\text { strength(MPa) }\end{array}$ & $\begin{array}{c}11 \\
(2)\end{array}$ & $\begin{array}{c}14 \\
(6)\end{array}$ & $\begin{array}{c}27 \\
(4)\end{array}$ & $\begin{array}{c}12 \\
(5)\end{array}$ & $\begin{array}{c}16 \\
(3)\end{array}$ \\
\hline
\end{tabular}

(standard deviation)

られている。

\section{3. 実 験 装}

Fig. 1 は本実験に使用した装置の概略図である。軸荷重を負荷す るための材料試験機の容量は $100 \mathrm{t}$, 剛性は約 $2 \times 10^{5} \mathrm{~N} / \mathrm{cm}$ である。 試験機はサーボコントロール方式を採用しており,ここではすべて 軸ひずみ制御で実験を行い，その速度を $1.3 \times 10^{-4} / \mathrm{sec}$ に統一し た。封圧負荷装置の容量は $100 \mathrm{MPa}$ であり,サーボ機構により実験 中常に, 封圧の值を一定に維持できる。一方, 間隙ガス圧負荷装置 の容量は $50 \mathrm{MPa}$ で, この装置は単なる増圧器であるため, 実験中 常に, ガス圧を一定に制御することは不可能であり, そのため間隙 ガス圧試験においては, 石炭の変形に伴い間隙ガス圧も若干変動す る。なお，間隙ガスは安全を考慮し，窒素ガスを使用した。

\section{4. 実 験 結 果}

石炭供試体内に存在する間隙ガス圧が, 石炭の力学的挙動にどの ような影響を与えるかを検討するため, 封圧試験ならびに間隙ガス

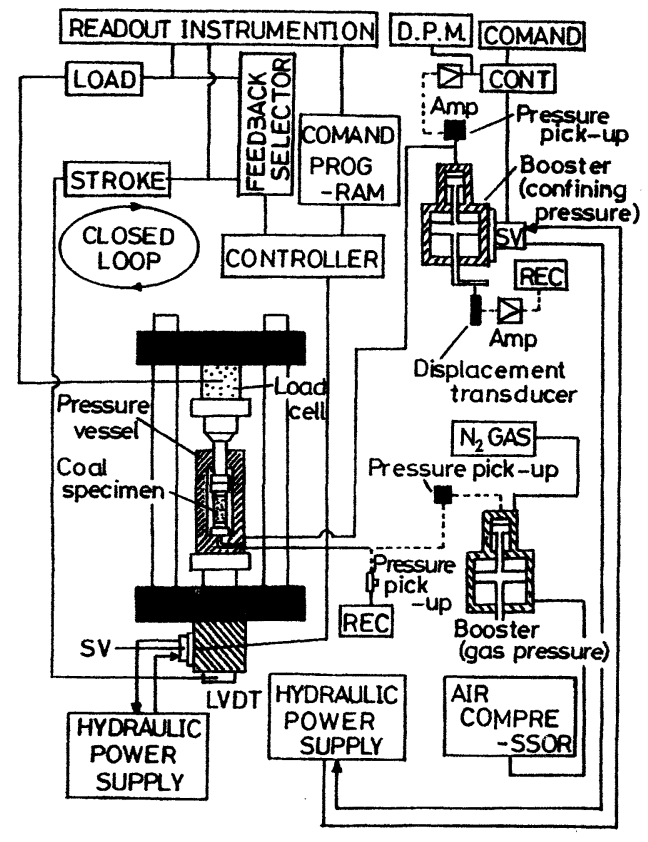

Fig. 1 Schematic diagram of apparatus for confining compression and pore gas pressure tests.
圧試験を行い比較した。以下に封圧試験, 間隙ガス圧試験結果につ いて示す。

\section{$4 \cdot 1$ 封圧試験}

石炭供試体をベッセル内にセットし, 封庄, 軸荷重の順で載荷し, 差応力一軸ひずみ曲線を求めた。Fig. 2，3 はそれぞれ芦別炭の $\mathrm{AS}-(\mathrm{A}), \mathrm{AS}-\mathrm{B}$ ) 供試体, Fig. 4, 5, 6 は赫平炭の $\mathrm{AK}-(\mathrm{A})$, $\mathrm{AK}$ - (B), $\mathrm{AK}$ - (C) 供試体の代表的差応力一軸ひずみ曲線である。 綐軸は差応力, 横軸は軸ひずみで, 図中の $P_{c}$ は設定封圧を表して いる。また差応力ー軸ひずみ曲線の点線で表示した部分は，大きな 破壊音を伴う激しい脆性破壊を発生した位置であり, 試験機のサー ボ機構の追従が不可能であったことを示している。

図からいずれの供試体む設定封圧の増加に伴い最大差応力点も増 加していることがわかる。一方, 変形挙動に関しては, 若干の例外 ああるが設定封圧が低い場合には脆性延性遷移および延性挙動が支 配的であるが, 設定封圧が高くなるに従い, 脆性挙動が卓越する傾 向がみられる。差応力一軸ひずみ曲線の立ち上がりから最大差応力 点付近までの平均的勾配を变形係数と定義すれば, 設定封圧の増加 に伴い変形係数む明らかに増加する傾向が認められる。また限界ひ ずみと設定封圧の間には, 明瞭な関連性は得られないが, 脆性挙動 を示した供試体の方が脆性延性遷移および延性挙動を示したものに 比べ，限界ひずみは小さい傾向を示していることがうかがわれる。

実験終了後, 供試体の肉眼観察を試みた。その結果, 脆性延性遷 移および延性的に破壊した供試体は比較的細かく破壊されており， 脆性的に破壊したものはせん断面の存在が認められた。

また芦別炭と赤平炭の間には力学的な挙動の大きな相違はほとん ど認められず, 封圧下での, ここでの挙動は既報1)の結果とよく一 致している。

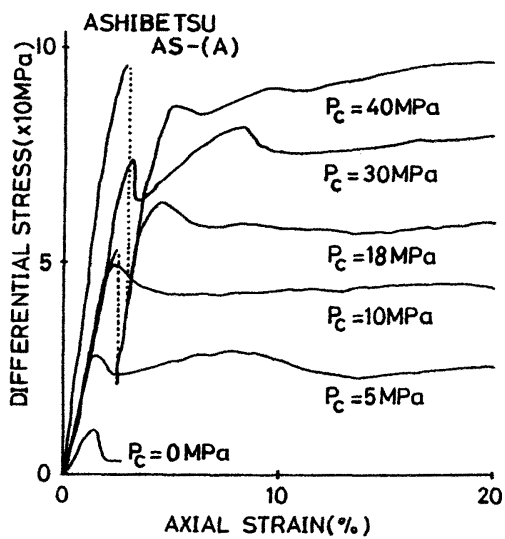

Fig. 2 Differential stress-strain curves of AS - (A) coal specimen at different confining pressures.

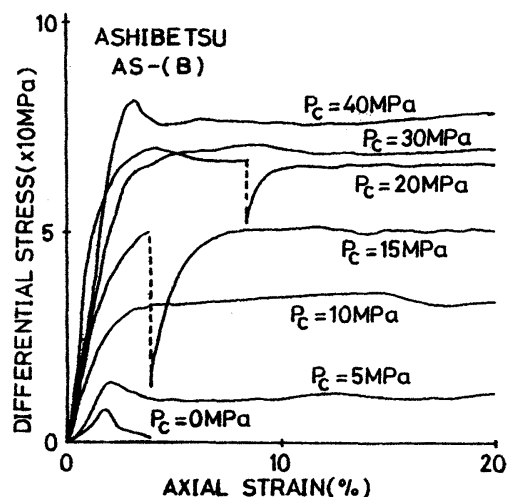

Fig. 3 Differential stress-strain curves of AS- (B) coal specimen at different confining pressures. 


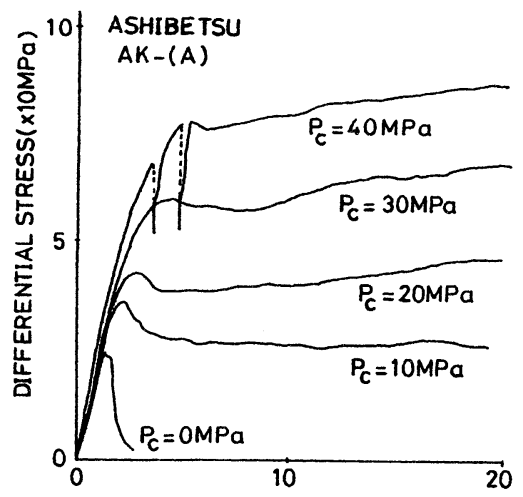

AXIAL STRAIN( $\%)$

Fig. 4 Differential stress-strain curves of AK-(A) coal specimen at different confining pressures.

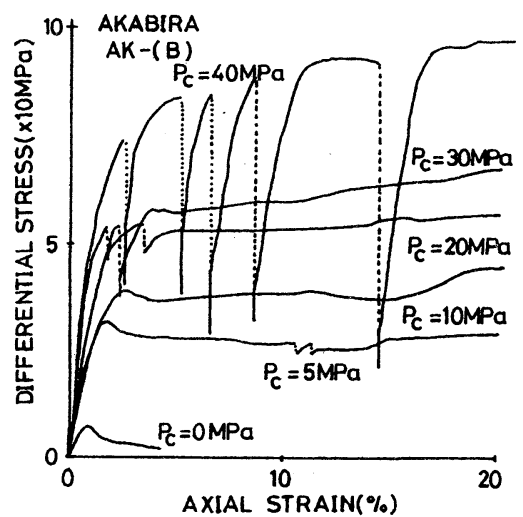

Fig. 5 Differential stress-strain curves of AK- (B) coal specimen at different confining pressures.

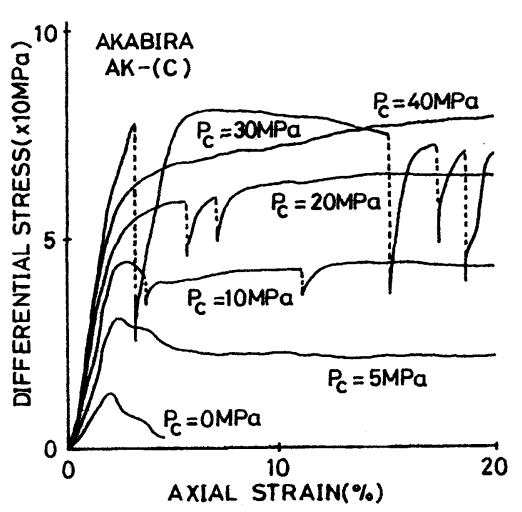

Fig. 6 Differential stress-strain curves of AK- (C) coal specimen at different confining pressures.

\section{$4 \cdot 2$ 間隙ガス圧試験}

間隙ガス圧試験の実施に関しては, 供試体内へのガス圧の飽和, すなわち供試体上部と下部の圧力が一致した状態を確認した後, 軸 載荷を行うこととした。そのため Fig. 7 に示すようにベッセルを 改良し，供試体の上部と下部の両方でガス圧をモニタできるように した。

設定封圧，間隙ガス圧までの載荷方法は岩石の透過率測定にしば しば用いられている，トランジェントパルス法778) の手順に従うこ とにした。すなわち，真空ポンプにより供試体内の空気抜きを行っ た後，任意の封圧下で，供試体の片側に窒素ガスの圧力パルス，0.2 $\mathrm{MPa}$ 程度を発生させ, 両方の圧力変化を時間とともにモ二タした。 この操作を封圧, 間隙ガス圧の設定値に達するまで繰り返し行った。 その際，供試体の上部と下部のエンドピースに連結した，それぞれ の圧力ピックアップにより，パルス発生後の圧力推移を測定した。 その結果, 時間経過とともに高圧側圧力（パルスを与えた側）は徐々 に減少, 低圧側圧力は徐々に増加し, 次第に両者の圧力が同じ值に 達することがモニ夕された。そこでこれらの実験デー夕を基に透過 率の値を求めるため, 圧力変化と時間の関係を片対数グラフにプロッ トしたが，直線近似可能なデー夕は比較的少なかった。この原因と しては温度に対する補償や大きな眝蔵タンク等の装備がなされてい ない本実験装置上の不備によるものと考えられる。さらに透過率の 比較的大きな供試体に対し，本方法の適応が困難であるという Brace ら7) の指摘を裏づけているあのとも考えられる。

しかしながら，ここでの実験条件や供試体寸法がほとんど同一で
あるため, パルス発生後, 両端の圧力が平衡状態に達するまでに要 する時間を透過率の定性的指標と考え，これらを比較して見ること にした。Fig.8，9 はこの結果の例を示したあので，供試体はそれ ぞれ $\mathrm{AS}-(\mathrm{A}), \mathrm{AK}-(\mathrm{A})$ である。縦軸は有効封圧（設定封圧と 平衡に達したときのガス圧差），横軸は平衡に達するまでに要した 時間を示している。図中の印は同一供試体を表している。両図とも 若干のばらつきを有するが，有効封圧が高くなるに従い各デー夕点 の間隔が大きくなり，平衡状態に達するまでの時間が長くなる傾向 にある。このことは他の供試体に関しても同様な結果が得られた。 これらの結果から，ガス透過性は供試体内の亀裂の閉塞度合之密接 に関連していると考えられる。なお，本実験においては装置の都合 上，圧力パルス発生後30分以内までに平衡に達したもののみを計測 対象とした。

ガス透過性試験で使用した供試体を用い間隙ガス圧試験を実施し た。すなわち高圧側と低圧側のガス圧が平衡に達した供試体を対象 に，このときの封圧および間隙ガス圧を設定值とし，軸荷重を負荷 し, 差応力一軸ひずみ曲線を求めた。Fig.10, 11 は芦別炭で, 供試 体はそれぞれ AS- (A)，（B) である。また Fig.12，13，14 は赤平 炭の $\mathrm{AK}-(\mathrm{A}),(\mathrm{B}),(\mathrm{C})$ 供試体である。図の縦軸は差応力, 横 軸は軸ひずみであり, 図中の $P_{c}$ は設定封圧, $P_{g}$ は設定間隙ガス圧 の值をそれぞれ表している。図より芦別炭も赤平炭も同様な傾向を 示している。設定封圧と設定間隙ガス圧との差, いわゆる有効封圧 の増加に伴い最大差応力点も増加しており, 変形挙動に関しては有 効封圧の増加に伴いわずかの例外はあるが, 脆性挙動が支配的にな

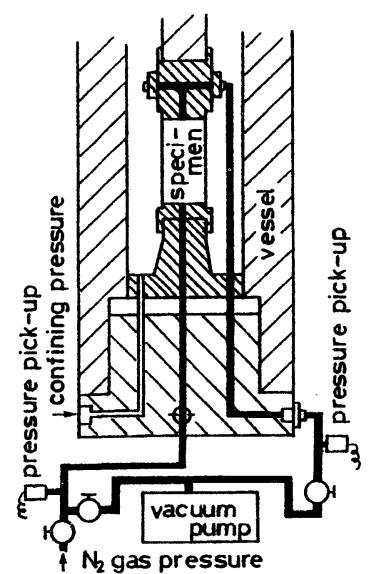

Fig. 7 Improved vessel monitering gas permeability of coal specimen.

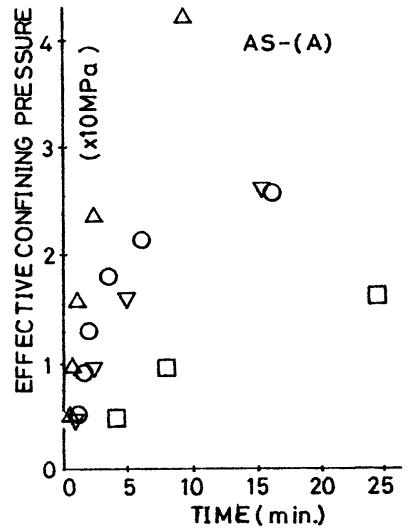

Fig. 8 Gas pereament time for AS- (A) coal specimen under different effective confining pressure.

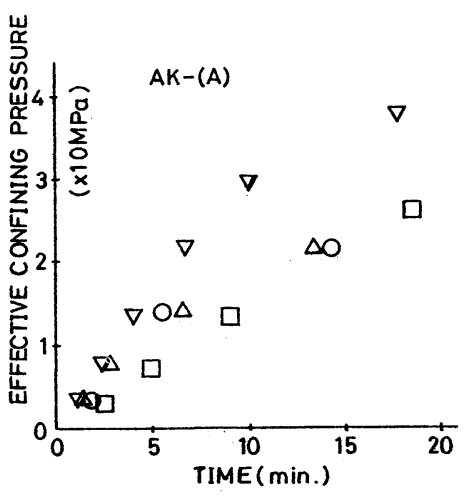

Fig. 9 Gas pereament time for AK-(A) coal specimen under different effective confining pressure. 


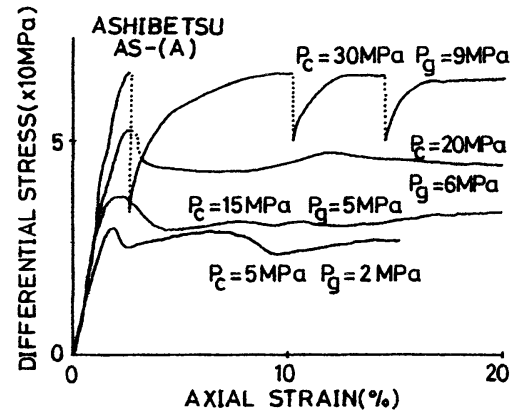

Fig.10 Differential stress-strain curves of AS- (A) coal specimen at different confining and pore gas pressure.

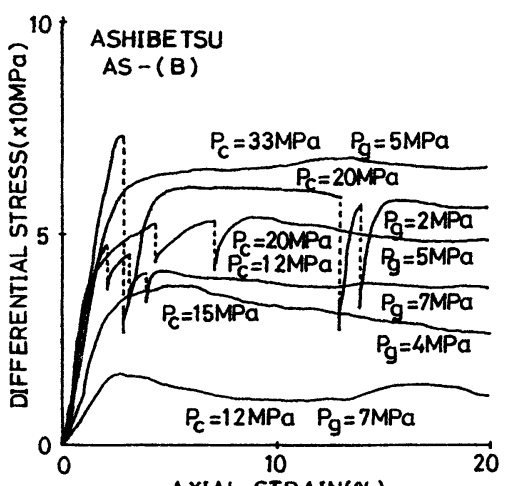

Fig.11 Differential stress-strain curves of AS-(B) coal specimen at different confining and pore gas pressure.

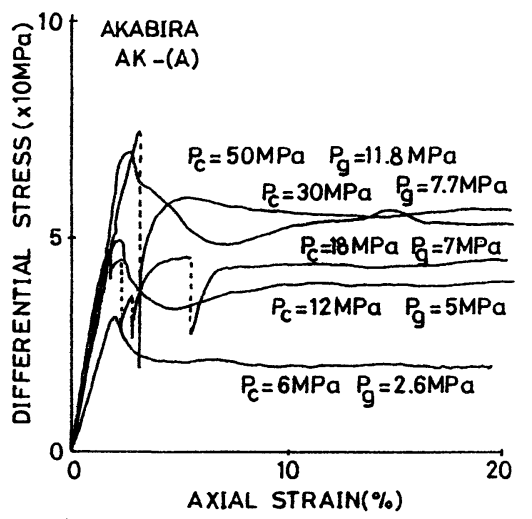

Fig.12 Differential stress-strain curves of $\mathrm{AK}-(\mathrm{A})$ coal specimen at different confining and pore gas pressure.

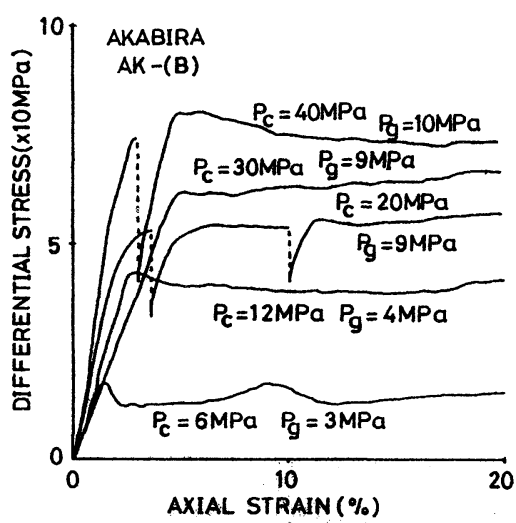

Fig.13 Differential stress-strain curves of $\mathrm{AK}-(\mathrm{B})$ coal specimen at different confining and pore gas pressure.

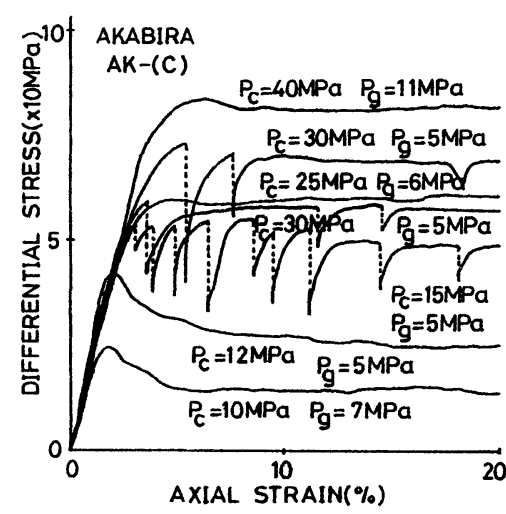

Fig.14 Differential stress-strain curves of $\mathrm{AK}-(\mathrm{C})$ coal specimen at different confining and pore gas pressure.
る傾向を有している。一方, 変形係数は有効封圧が大きくなるに従 い增加し, 限界ひずみの値は, かなりのばらつきはあるが, 脆性挙 動を示す場合の方が脆性延性遷移および延性挙動を示す場合に比べ 小さいことがわかる。これらの挙動は封圧試験結果と比較的よく類 似している。実験終了後の破壊状態の肉眼観察では, 封圧試験の場 合と同様な結果が得られた。

なお，本実験はすべて非排気条件で行われているため，供試体の 変形に伴い間隙ガス圧の値あ変化するが, その值は設定間隙ガス圧 のほぼ数\%以内であったことを付記しておく。

\section{5. 試験結果に対する考察}

ここでは上記の実験結果を踏まえ, 若干の考察を試みたい。一つ は変形と強度に関する有効封圧の法則の検証であり, 他は封圧とガ ス透過性の関連である。

まず全体的な変形挙動であるが, 封圧および間隙ガス圧試験の差 応力一軸ひずみ曲線を見ると，低封圧ならびに低有効封圧下ではい ずれの供試体も, 脆性延性遷移挙動や延性挙動を示し, 封圧および 有効封圧が高くなるに従い，脆性挙動が卓越する傾向が得られた。 また変形係数や限界ひずみに関しても, 両試験において全体的傾向 として, 比較的良い類似が認められた。しかしながら同一供試体の ほぼ同じ封圧と有効封圧の変形挙動を詳細に比較検討してみると, 必ずしあ良い一致が認められず, これについては, 供試体のばらつ き等によるものとも考えられ, 今後より多くのデータの蓄積が必要 と思われる。
次に，強度に関し有効封圧の法則が当てはまるかどうかを検討し たい。そこで封圧および間隙ガス圧試験で得られた差応力ー軸ひず み曲線を基に, 封圧および有効封圧と強度の関係をプロットした。 Fig.15，16は芦別炭の AS-(A)，(B)，Fig.17，18，19 は赤平炭の $\mathrm{AK}$ - (A), (B), (C) 供試体の結果である。縦軸は最大主応力で, 差応力ー軸ひずみ曲線の最大差応力点の值に封圧試験では封圧, 間 隙ガス圧試験では有効封圧を加えたものである。なお，延性挙動や ひずみ硬化を示す場合には軸ひずみ $20 \%$ で最大差応力の值を採用 した。図の横軸は最小主応力で, 封圧または有効封圧を表しており, それぞれ封圧および間隙ガス圧試験に対応している。図中の黒丸は 封圧試験, 白丸は間隙ガス圧試験のデータを示している。いずれの 場合も, 最小主応力の増加とともに最大主応力も增加していること がわかる。また, 両試験結果を比べてみると, 若干のばらつきはあ るが, 比較的良く一致しており, 強度に関し, ほぼ有効応力の法則 が成立することが理解できる。

封圧の大きさとガス透過性の間には，定性的ではあるが密接な関 係か認められ, 有効封圧の増加とともに, 石炭供試体内のガス透過 性が悪くなることがわかった。ここではこれに関し考察したい。石 炭供試体は封圧, すなわち静水圧を加えた後, 軸荷重を負荷し, 破 壊にいたらしめる。そこで静水圧負荷過程での石炭の体積ひずみと, $\mathrm{AE}$ イベントの発生頻度を計測することにした。供試体寸法, 被覆 等は封圧試験の場合と同様であるが，供試体の表面に体積ひずみ測 定用ストレゲージと AE センサーが直接貼付けられている。なお， $\mathrm{AE}$ センサーの上部には，静水圧の影響を防ぐための金属性キャッ 


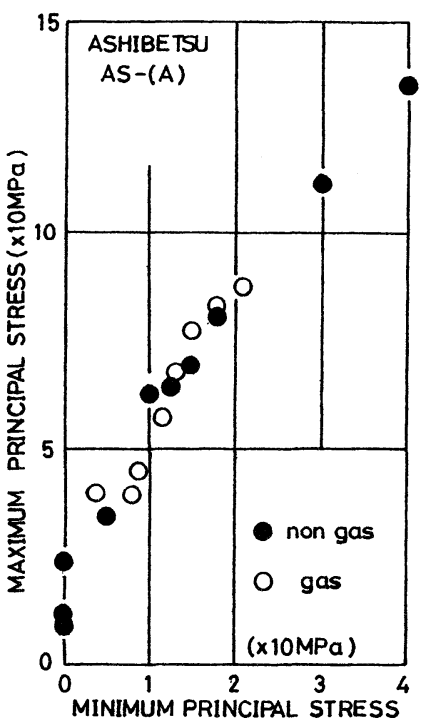

Fig.15 Maximum principal stress versus minimum principal stress at fracture strength for AS-(A) coal specimen.

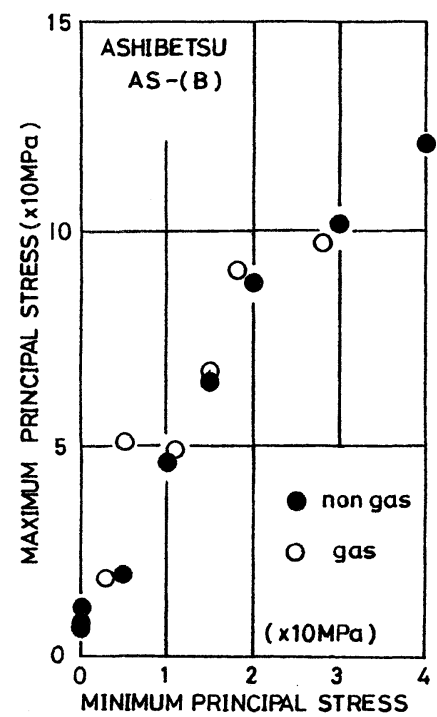

Fig.16 Maximum principal stress versus minimum principal stress at fracture strength for AS- (B) coal specimen.

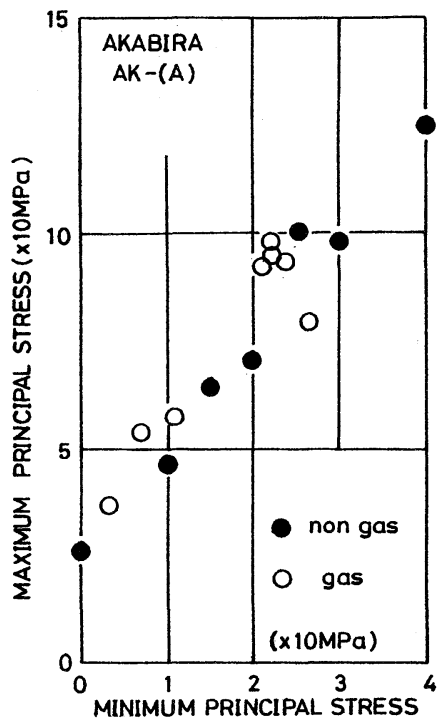

Fig.17 Maximum principal stress ver sus minimum principal stress at fracture strength for $\mathrm{AK}$ (A) coal specimen.

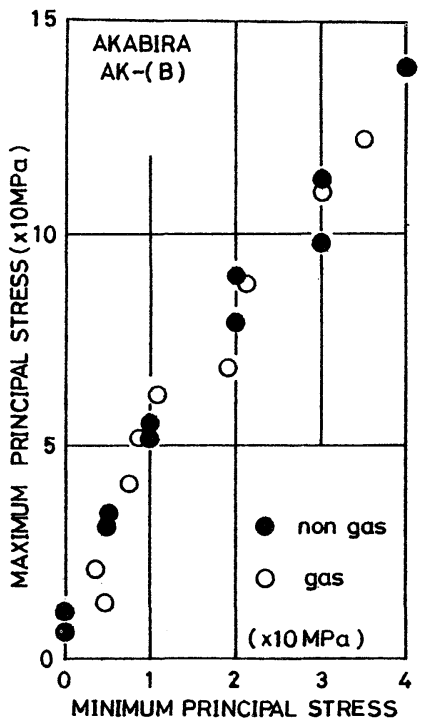

Fig.18 Maximum principal stress versus minimum principal stress at fracture strength for $\mathrm{AK}$ (B) coal specimen.

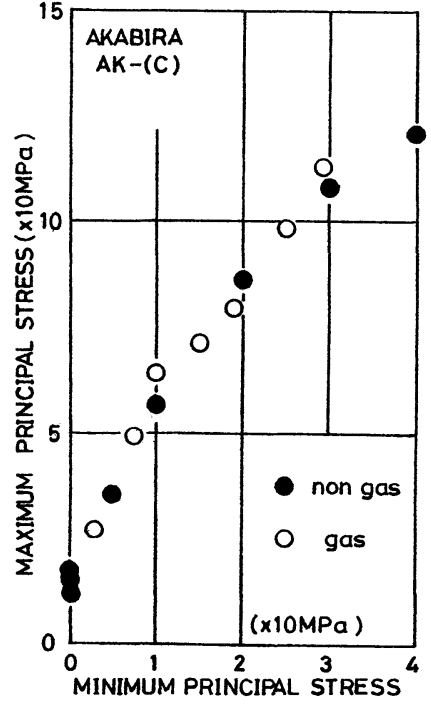

Fig.19 Maximum principal stress versus minimum principal stress at fracture strength for AK(C) coal specimen.
プがかぶせられている。Fig.20はAE計測装置のシステム図であ り, 石炭供試体で発生した AE 信号は直径 $4 \mathrm{~mm}$, 共振周波数 $2 \mathrm{M}$ $\mathrm{Hz}$ の圧電型センサーで受信され, プリアンプ, 弁別器に送られる。 検出された AE 信号のイベント数はカウンタで計数され記録され る。また波形は常にオシロスコープでモニタされ, 必要な波形はフ ロッピーに蓄えられる。

Fig.21は静水圧試験結果の例を示したもので, 供試体は $\mathrm{AK}$-（A）である。図の縦軸は静水圧, 横軸は体積ひずみおよび 静水圧 $5 \mathrm{MPa}$ 毎に発生した AEイベント数の頻度を表している。 静水圧一体積ひずみ曲線を見ると, 低静水圧域では非線形でしかも その勾配が小さく, 高静水圧域では比較的線形で勾配が大きいこと がわかる。また, AEイベント数は低静水圧域では発生数が多いが, 高静水圧域では少なくなる傾向を有している。これらの結果から, 低静水圧域は供試体内亀裂の閉塞段階, 高静水圧域は閉塞終了を示 しているものと判断され，このことがガス透過性や変形挙動に直接

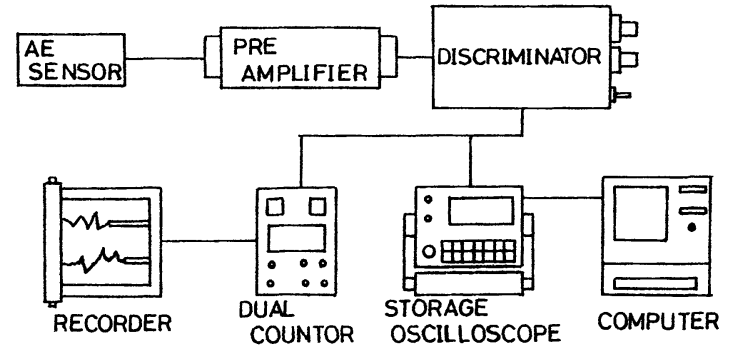

Fig.20 Schematic diagram of apparatus to monitering AE activities of coal specimen.

影響を及ぼすと考えられる。すなわち，供試体内の亀裂は低静水圧 下で，その閉塞割合が少ないため透過性が良く，高静水圧下では亀 裂の閉塞割合が多くなるため，透過性が悪くなるものと考えられる。 


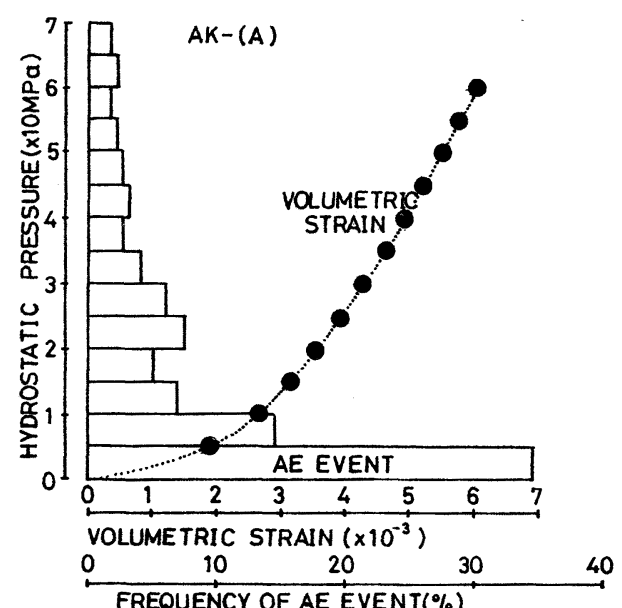

Fig.21 Volumetric strain and frequency of AE event under hydrostatic pressure.

一方, 前者では開いた状態の亀裂が多いため, 変形は脆性延性遷移 挙動および延性挙動が卓越し, 後者では開いた亀裂が少なくなるた め, 脆性挙動が支配的となるものと解釈される。

\section{6. 結}

芦別および赤平炭鉱で採取した 5 種の石炭供試体を対象に,ひず み速度 $1.3 \times 10^{-4} / \mathrm{sec}$, 封圧, 間隙ガス圧を $40 \mathrm{MPa}$ 以下の範囲内
で，窒素ガスを用い，封圧，および間隙ガス圧試験を実施した。 その結果, 封圧および有効封圧の増加に伴い強度は増加し, 変形 は脆性延性遷移または延性挙動から脆性挙動へと移行する傾向が得 られ, 強度に関し, 有効封圧の法則が成立することがわかった。 また，ガス透過性は，低静水圧域では良く，高静水圧になるに従 い悪くなる傾向が認められ, これらの現象と変形挙動は, 供試体内 に存在する亀裂の静水圧に対する閉塞割合と密接な関連を有してい ることがわかった。

謝辞 本実験遂行に当たり, 協力して頂いた本学卒業の大学院 生と学部学生諸氏に感謝申し上げる。

\section{引用文献}

1）後藤龍彦 - 佐藤干城・福島 篤・出口剛太 : 日本鉱業会誌, Vol.101, p. 761767, (1985)

2) Handin, J., Hager, R.V., Friedman, Jrvd. M. and Feather, J. W.: Bull. Am. Ass. Petrol. Geol., Vol. 47, p. 717-755, (1963)

3）後藤龍彦・佐藤干城・深井 哲・入江正幸：日本釷業会誌，Vol. 89, p. 393398, (1982)

4) Brace, W. F. and Martin, R. J.: Int. J. Rock Mech. Min. Sci. ,Vol. 5, p .415 426, (1968)

5）後藤龍彦・佐藤干城・田上正義：北海道応用地学合同研究会 論文集, Vol. 2, p.86-91, (1991)

6) Nakajima, I., Yang, Qi., Ujihira, M. and Ma, F.: Hokkaido Geotechnics, Vol. 1, p. $116-123,(1990)$

7) Brace. W. F., Walsh, J. B. and Frangos, W. T.: J. Geophys. Res., Vol. 73, p. 2225-2236, (1968)

8）高橋 学・平田実雄・小出 仁: 応用地質, Vol. 31, p. 1-10, (1990) 